\title{
Analysis of Air Pollution Trends in Beijing, China
}

\author{
Anbu Clemensis Johnson
}

NUIST Reading Academy, 219 Ningliu Road, Nanjing, Jiangsu, 210044 P.R. China

\begin{abstract}
Article Info
Volume 7, Issue 6

Page Number: 372-376

Publication Issue :

November-December-2020
\end{abstract}

\section{Article History}

Accepted : 25 Dec 2020

Published : 30 Dec 2020

\section{ABSTRACT}

Air pollution is a worldwide problem affecting not only the source location, but the globe as a whole. The current study aims to analyse the standard six air pollutants and air quality index (AQI) in Beijing, China. Air quality data was collected from 2014 to 2020 for temporal analysis. The average maximum values of the air pollutants and AQI during the period analysed were, $\mathrm{PM}_{2.5}$ : $74.4 \mu \mathrm{g} / \mathrm{m}^{3}, \mathrm{PM}_{10}: 107.3 \mu \mathrm{g} / \mathrm{m}^{3}, \mathrm{SO}_{2}: 20.7 \mu \mathrm{g} / \mathrm{m}^{3}, \mathrm{CO}: 1.5 \mathrm{mg} / \mathrm{m}^{3}, \mathrm{NO}_{2}: 56.3$ $\mu \mathrm{g} / \mathrm{m}^{3}, \mathrm{O}_{3}: 173.1 \mu \mathrm{g} / \mathrm{m}^{3}$ and AQI: 118 . Maximum and minimum values of the primary pollutants occurred predominantly during winter and summer months, while $\mathrm{O}_{3}$ exhibited an opposite trend. All air pollutants and AQI declined over the years. Significant reduction of over $50 \%$ was archived for $\mathrm{PM}_{2.5}, \mathrm{PM}_{10}, \mathrm{SO}_{2}, \mathrm{CO}$ and less than $5 \%$ for $\mathrm{O}_{3}$. The air pollution trend in Beijing has shown substantial improvement. In 2020, all air pollutants except $\mathrm{PM}_{2.5}$ achieved the national ambient air quality standard. This realisation can be credited to the effective policies implemented by the Chinese government.

Keywords: Air quality index, Data analysis, Primary pollutants, Ozone, Particulate matter

\section{INTRODUCTION}

Air pollution is a major problem in the world and industrialisation and economic development has resulted in indiscriminate release of various air pollutants into the atmosphere. Increasing air pollutants is directly linked to poor visibility, health problems affecting breathing, lungs, heart and others, and increase in global atmospheric temperature [1-3]. Recently scientists around the world have raised caution alarms on the deteriorating global air quality situation. Universally accepted measured five primary pollutants are $\mathrm{PM}_{2.5}, \mathrm{PM}_{10}, \mathrm{SO}_{2}, \mathrm{CO}$ and $\mathrm{NO}_{2}$. The air quality index (AQI) is based on the five primary pollutants and $\mathrm{O}_{3}$ which is a secondary pollutant. According to world air quality report in 2019 by IQAir, China stands eleventh and Beijing its capital ninth in the world for the highest average $\mathrm{PM}_{2.5}$ concentration [4]. Main industries in the region are heavy industries, metallurgy, chemicals and others [5]. Pollution in Beijing can be attributed to population growth, surge in motor vehicles, increase in industrial production, topography and seasonal weather [6]. Ambient air quality standards in China were 
introduced in 2012 (GB 3095-2012) and the primary standards for urban areas are given in Table 1 [7]. Major PM2.5 sources in Beijing are motor vehicles, coal burning, industrial production and construction dust. The concentration of the primary pollutants has been found to decrease over the years [9]. Study by Han et al. [10] has shown that annual average $\mathrm{PM}_{2.5}$ concentration in Beijing declined by about $42 \%$ from 2013 to 2017, resulting in the decline of respiratory and cardiovascular mortality by about $23 \%$ and $34 \%$. In order to improve the air quality the Chinese government has taken measures such as reduction of sulphur dioxide and nitrogen oxides during the $11^{\text {th }}$ and $12^{\text {th }}$ five year plan periods. Air pollution prevention and control action plan was introduced in 2013 to reduce the particulate matter concentration in stages of $25 \%, 20 \%$, and $15 \%$ by 2017 . Some of the important actions taken by the governing body to improve the air quality were, introduction of natural gas thermal power cogeneration in power plants, renovation of coal fired boilers and renovation of old one storey houses for efficient residential heating [9].

The current research work intends to study the changes in the prominent six air pollutants and AQI in Beijing municipality from 2014 to 2020. Objectives of the study were to identify the months and seasons with maximum impact from air pollutants and its current status.

Table 1: Chinese air pollution primary standards and WHO guidelines.

\begin{tabular}{llcc}
\hline Pollutant & $\begin{array}{c}\text { Averaging } \\
\text { time }\end{array}$ & $\begin{array}{c}\text { Chinese } \\
\text { Standards } \\
\text { 2012 [7] }\end{array}$ & $\begin{array}{c}\text { WHO } \\
\text { 2006 } \\
{[8]}\end{array}$ \\
\hline $\mathrm{PM}_{2.5}$ & 24 hours & 75 & 25 \\
$\left(\mu \mathrm{g} / \mathrm{m}^{3}\right)$ & annual & 35 & 10 \\
$\mathrm{PM}_{10}$ & 24 hours & 150 & 50 \\
$\left(\mu \mathrm{g} / \mathrm{m}^{3}\right)$ & annual & 70 & 20 \\
$\mathrm{O}_{3}\left(\mu \mathrm{g} / \mathrm{m}^{3}\right)$ & 8-hour & 160 & 100
\end{tabular}

\begin{tabular}{llcc} 
& maximum & & \\
$\mathrm{NO}_{2}\left(\mu \mathrm{g} / \mathrm{m}^{3}\right)$ & 24 hours & 80 & - \\
& annual & 40 & 40 \\
$\mathrm{SO}_{2}\left(\mu \mathrm{g} / \mathrm{m}^{3}\right)$ & 24 hours & 150 & 20 \\
& annual & 60 & - \\
$\mathrm{CO}\left(\mathrm{mg} / \mathrm{m}^{3}\right)$ & 24 hours & 4 & - \\
\hline
\end{tabular}

\section{MATERIALS AND METHODS}

Beijing municipality is situated at the north edge of the North China Plain and is the capital of China. It covers a total area of $16,800 \mathrm{~km}^{2}$ with the population of 21.5 million [11,12]. The air pollution data for the Beijing municipality were obtained from aqistudy.cn website. The pollutants studied were $\mathrm{PM}_{2.5}, \mathrm{PM}_{10}, \mathrm{SO}_{2}$, $\mathrm{CO}, \mathrm{NO}_{2}, \mathrm{O}_{3}$ and AQI. Monthly average values were calculated using each day's hourly data. The data collected until 20 ${ }^{\text {th }}$ December 2020 was used in the analysis. It is anticipated that the influence caused by the data deficiency on the analysis would be minimal. The four seasons in the region considered in the study were spring (March, April and May), summer (June, July and August), autumn (September, October and November) and winter (December, January and February).

\section{RESULTS AND DISCUSSION}

\section{Temporal Characteristics of Air Pollutants}

\section{A. Monthly Variation of Air Pollutants and AQI}

The monthly average values of the air pollutants and AQI for seven years are presented in Figure 1. The changes exhibited by the primary pollutants were similar with maximum values occurring during the beginning and end of the year and minimum values during the middle of the year. Peak values of the air pollutants $\left(\mathrm{PM}_{2.5}, \mathrm{PM}_{10}, \mathrm{SO}_{2}, \mathrm{CO}, \mathrm{NO}_{2}, \mathrm{O}_{3}\right)$ and $\mathrm{AQI}$ were $74.4 \mu \mathrm{g} / \mathrm{m}^{3}, 107.3 \mu \mathrm{g} / \mathrm{m}^{3}, 20.7 \mu \mathrm{g} / \mathrm{m}^{3}, 1.5 \mathrm{mg} / \mathrm{m}^{3}$, $56.3 \mu \mathrm{g} / \mathrm{m}^{3}, 173.1 \mu \mathrm{g} / \mathrm{m}^{3}$ and 118. Transition from high to low values generally occurred during March 
until May and change from low to high values during October. The minimum values were during July and August, and May for CO. While the trend exhibited by $\mathrm{O}_{3}$ and AQI were contrary when compared with the primary air pollutants, with high values occurring during the middle of the year (June) and low values during November and September. Similar trend was also observed by Zhao et al. [13]. These monthly variations indicate the contribution of climatic conditions in dispersing and removing air pollutants.

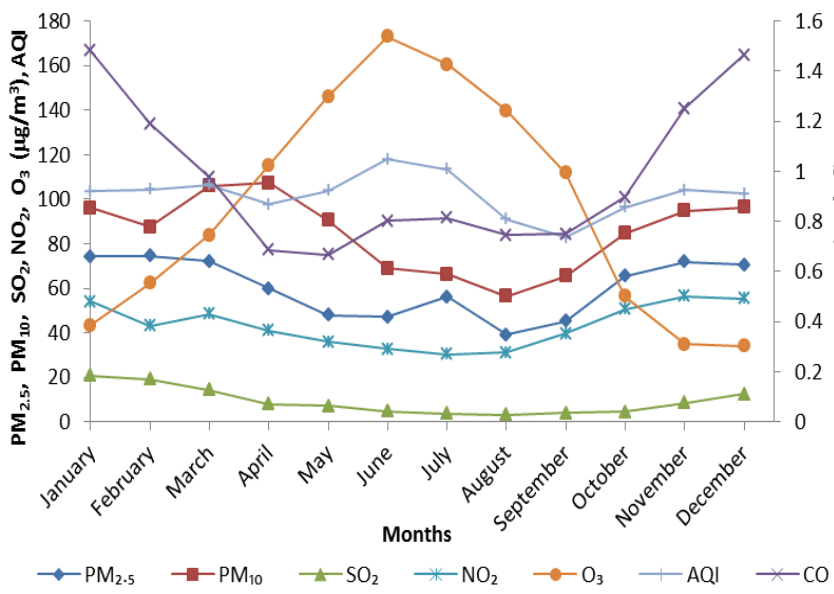

Figure 1: Monthly variation of air pollutants and AQI in Beijing.

\section{B. Seasonal Variation of Air Pollutants and AQI}

Seasonal variation of the prominent air pollutants and AQI are given in Figure 2. The maximum values of $\mathrm{PM}_{2.5}, \mathrm{SO}_{2}, \mathrm{CO}, \mathrm{NO}_{2}\left(73 \mu \mathrm{g} / \mathrm{m}^{3}, 17.5 \mu \mathrm{g} / \mathrm{m}^{3}, 1.4 \mathrm{mg} / \mathrm{m}^{3}\right.$, $50.8 \mu \mathrm{g} / \mathrm{m}^{3}$ ) occurred in winter. This is predominantly caused due to heating sources used during winter in Beijing and seasonal climatic conditions with low wind speed and high relative humidity [13]. Maximum value of $\mathrm{PM}_{10}\left(101.2 \mu \mathrm{g} / \mathrm{m}^{3}\right)$ occurred during spring, this is because of the heating sources and wind erosion dust during spring [14]. $\mathrm{O}_{3}$ concentration was highest during summer due to higher solar radiation and temperature which promotes photochemical activity suitable for $\mathrm{O}_{3}$ formation [15]. AQI reached a maximum value during summer, which may be attributed to high levels of $\mathrm{O}_{3}$. The minimum values for $\mathrm{PM}_{2.5}, \mathrm{PM}_{10}, \mathrm{SO}_{2}, \mathrm{NO}_{2}$ and $\mathrm{CO}$ were during summer and spring. This decrease is predominantly caused by maximum precipitation during the summer months. One of the reasons for low values of $\mathrm{CO}$ during spring which extends through summer could be through photochemical degradation of $\mathrm{CO}$ [13]. The minimum value of $\mathrm{O}_{3}$ occurred during winter season due to the lack of intense solar radiation. Minimum AQI value occurred during autumn. The fluctuations in the AQI values were minimal.

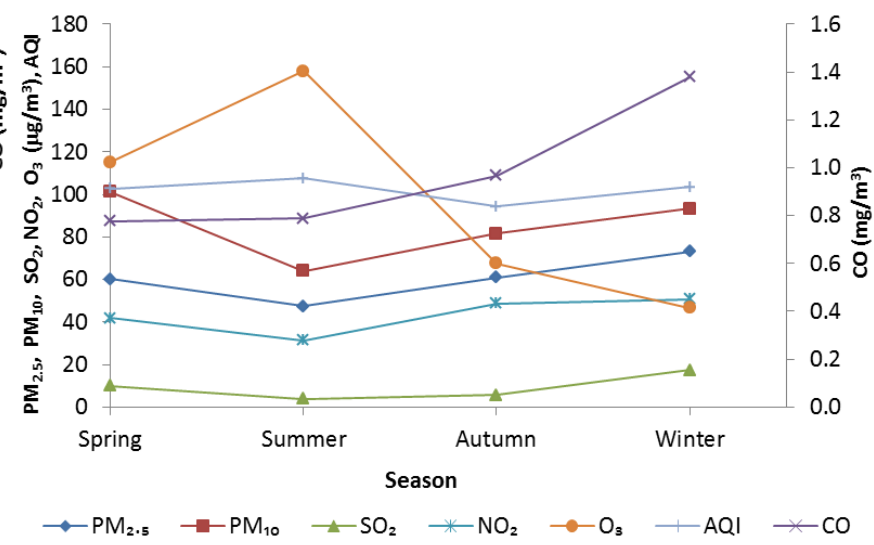

Figure 2: Seasonal variation of air pollutants and AQI in Beijing.

\section{Annual variation of Air Pollutants and AQI}

The annual values of the pollutants and AQI are given in Figure 3. It can be seen that all air pollutants and AQI have shown a decreasing trend over the years. The percentage reduction achieved for $\mathrm{PM}_{2.5}, \mathrm{PM}_{10}$, $\mathrm{SO}_{2}, \mathrm{NO}_{2}, \mathrm{CO}, \mathrm{O}_{3}$ and $\mathrm{AQI}$ were 55.6, 51.9, 82.3, 46.8, 50.8, 4.2 and 37.7. Maximum reduction was achieved for $\mathrm{SO}_{2}$ and minimum for $\mathrm{O}_{3}$. This can be directly linked to the policies and actions taken by the central administration and local governing bodies. In 2020, the $\mathrm{PM}_{2.5}$ was $2.7 \mu \mathrm{g} / \mathrm{m}^{3}$ greater than the annual Chinese standard. However, $\mathrm{PM}_{10}, \mathrm{SO}_{2}, \mathrm{CO}, \mathrm{NO}_{2}$ and $\mathrm{O}_{3}$ decreased by $13.9 \mu \mathrm{g} / \mathrm{m}^{3}, 56.3 \mu \mathrm{g} / \mathrm{m}^{3}, 3.4 \mathrm{mg} / \mathrm{m}^{3}$, 
$10.8 \mu \mathrm{g} / \mathrm{m}^{3}$ and $65.1 \mu \mathrm{g} / \mathrm{m}^{3}$ and conformed to the 2012 Chinese standards [7]. Similar decreasing trend was also reported by Tian et al. [16]. When compared with the WHO standards $\mathrm{PM}_{2.5}$ and $\mathrm{PM}_{10}$ were 27.7 $\mu \mathrm{g} / \mathrm{m}^{3}$ and $36.1 \mu \mathrm{g} / \mathrm{m}^{3}$ greater, while $\mathrm{NO}_{2}$ and $\mathrm{O}_{3}$ were $10.8 \mu \mathrm{g} / \mathrm{m}^{3}$ and $5.1 \mu \mathrm{g} / \mathrm{m}^{3}$ lower and comply with the 2006 WHO standards. It should also be borne in mind that lockdown measures taken because of the COVID-19 pandemic would have also contributed to the decline in the air pollution during 2020. The decreasing trend of the air pollutants and AQI is a positive sign and further measures could make Beijing comparable with world cities with clean air.

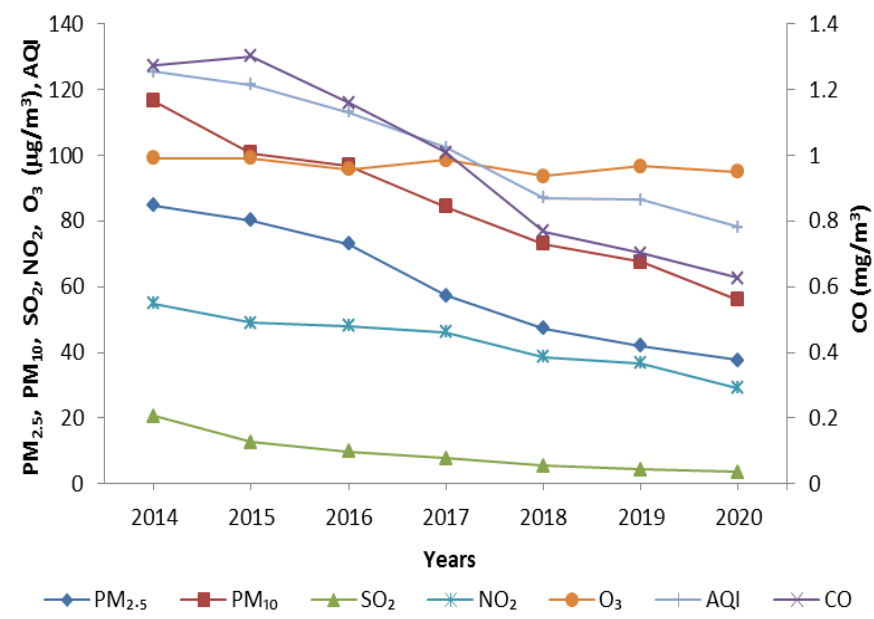

Figure 3: Annual variation of air pollutants and AQI in Beijing.

\section{CONCLUSION}

The comprehensive study of the air pollution and AQI data in Beijing was successfully conducted for the period 2014 - 2020. The study indicated high concentration of air pollutants in the atmosphere during the year beginning and end (late autumn to winter) and low during middle of the year in summer. Exceptions were observed for maximum $\mathrm{PM}_{10}$ and minimum $\mathrm{CO}$ concentrations which occurred during spring. Opposite trend was exhibited by $\mathrm{O}_{3}$ and $\mathrm{AQI}$ with high values during summer and low values in winter and autumn. All air pollutant concentrations and AQI showed a decreasing trend with maximum reduction archived for $\mathrm{SO}_{2}(82.3 \%)$ and minimum for $\mathrm{O}_{3}$ (4.2\%). New technological developments and stringent regulation could further improve the air quality.

\section{ACKNOWLEDGEMENT}

This research did not receive any specific grant from funding agencies in the public, commercial, or notfor-profit sectors.

\section{REFERENCES}

[1] C.A. Pope, R.T. Burnett, M.J. Thun, E.E. Calle, D. Krewski, K. Ito, G.D. Thurston, "Lung cancer, cardiopulmonary mortality, and long-term exposure to fine particulate air pollution," J. Am. Med. Assoc. 2002, 287(9), 1132-1141. DOI: 10.1001/jama.287.9.1132.

[2] P. Gallagher, W. Lazarus, H. Shapouri, R. Conway, F. Bachewe, A. Fischer, "Cardiovascular disease-Risk benefits of clean fuel technology and policy: A statistical analysis," Energy Policy 2010, 38(2), 1210-1222. DOI:

10.1016/j.enpol.2009.11.013.

[3] A. Peters and C.A. Pope, "Cardiopulmonary mortality and air pollution," Lancet 2002, 360, 1184-1185. DOI: 10.1016/S0140-6736(02)11289$\mathrm{X}$.

[4] IQAir, "2019 World Air Quality Report Region \& City PM2.5 Ranking," https://www.iqair.com/world-most-pollutedcities/world-air-quality-report-2019-en.pdf, accessed 20 December 2020.

[5] China Provinces, "Map of China - Province and Industry," https://www.bdo.global/getmedia/b1cfca59-6ba64a16-8bf4-db62b25866f8/Chinaprovinces.pdf.aspx, accessed 20 December 2020. 
[6] M.F. Ye, "Causes and Consequences of Air Pollution in Beijing, China," in Environmental ScienceBites, K.A. Clark, T.R. Shaul and B.H. Lower, Ed. Ohio: The Ohio State University, 2015, pp. 1-9.

[7] Air Quality Standards, "China: Air Quality Standards," https://www.transportpolicy.net/standard/chinaair-quality-standards, accessed 20 December 2020.

[8] WHO, "WHO Air quality guidelines for particulate matter, ozone, nitrogen dioxide and sulfur dioxide: global update 2005," https://apps.who.int/iris/bitstream/handle/10665/ 69477/WHO_SDE_PHE_OEH_06.02_eng.pdf?se quence=1, accessed 20 December 2020.

[9] UNEP, "A Review of Air Pollution Control in Beijing: 1998-2013," Nairobi: United Nations Environment Programme.

[10] L. Han, Z. Sun, T. Gong, X. Zhang, J. He, Q. Xing, Z. Li, J. Wang, D. Ye and S. Miao, "Assessment of the short-term mortality effect of the national action plan on air pollution in Beijing, China," Environmental Research Letters 2020, 15, 034052. DOI: 10.1088/17489326/ab6f13.

[11] ChinaToday, "Beijing, The Capital of China," http://www.chinatoday.com/city/beijing.htm, accessed 20 December 2020.

[12] City population, "CHINA: Beijing," https://www.citypopulation.de/en/china/cities/be ijing, accessed 20 December 2020.

[13] Y. Zhou, S. Cheng, D. Chen, J. Lang, G. Wang, T. $\mathrm{Xu}, \mathrm{X}$. Wang and S. Yao, "Temporal and Spatial Characteristics of Ambient Air Quality in Beijing, China," Aerosol and Air Quality Research 2015, 15, 1868-1880. DOI: 10.4209/aaqr.2014.11.0306.

[14] X. Wei, "Development of Atmospheric Pollutants Emission Inventories for China and Interaction of Air Pollution among Typical Region," Master's thesis. Beijing: Beijing University of Technology, 2013.

[15] X.Y. Tang, Y.H. Zhang and M. Shao, "Atmospheric Environmental Chemistry," 2nd ed. Beijing: Higher Education Press, 2006.

[16] Y. Tian, Y. Jiang, Q. Liu, D. Xu, S. Zhao, L. He, $\mathrm{H}$. Liu and $\mathrm{H}$. $\mathrm{Xu}$, "Temporal and spatial trends in air quality in Beijing," Landscape and Urban Planning 2019, 185, 35-43. DOI: 10.1016/j.landurbplan.2019.01.006.

\section{Cite this article as :}

Anbu Clemensis Johnson, "Analysis of Air Pollution Trends in Beijing, China", International Journal of Scientific Research in Science and Technology (IJSRST), Online ISSN : 2395-602X, Print ISSN : 23956011, Volume 7 Issue 6, pp. 372-376, NovemberDecember 2020. Available at doi : https://doi.org/10.32628/IJSRST207662

Journal URL : http://ijsrst.com/IJSRST207662 